\title{
Curriculum Implementation in Biology Program of Universitas Negeri Surabaya
}

\author{
Ahmad Bashri ${ }^{1}$, Rinie Pratiwi Puspitawati ${ }^{2}$, Muslimin Ibrahim ${ }^{3}$ \\ Biology Department \\ Universitas Negeri Surabaya \\ Surabaya, Indonesia \\ ${ }^{2}$ riniepratiwi@unesa.ac.id
}

\begin{abstract}
This study aims to describe the effectiveness of curriculum implementation in the Biology Program, implementation of curriculum implementation in the Biology Program, and obstacles in implementing the curriculum. This research is an observational study, which observes curriculum documents and their implementation. The observed stages are planning, implementation, assessment, and obstacles stages in implementing the curriculum. The research instrument consisted of observation sheets of curriculum documents and their implementation, lecturer and education staff questionnaires, and student interview sheets. Data were analyzed descriptively. The results of the study that the curriculum implementation has been effective, the implementation is very good, and there are obstacles in the implementation of the curriculum planning stage, implementation stage, and assessment stage.
\end{abstract}

\section{Keywords—curriculum implementation; biology program}

\section{INTRODUCTION}

Curriculum is a set of plans and arrangements regarding the achievements of graduate learning, study materials, processes, and assessments that are used as guidelines for the implementation of the study program. Faculty of Mathematic and Natural Science Unesa's curriculum has adopted and adapted various trends and current regulations such as the development of science, technology, and art (science and technology), demands of the $21^{\text {st }}$ century, national standards of higher education, and has been designed to provide relevant experience for students, so that documents are realized curriculum (written curriculum). Curriculum document then becomes a reference to be implemented in learning (actual curriculum). Establishing curriculum by governments causes a shift in the policy actions of educational support from a technical rationale with a main focus on funding and resources to a pedagogical rationale with a main focus on student competencies [1], so curriculum changes need to be done by institutions or universities.

Curriculum that is implemented in principle is a curriculum that is developed based on the principles of curriculum development, which is relevant to the demands, needs, and development of the community, but also must be relevant between goals, content, delivery process, and assessment. Another principle that must also be considered is flexibility, continuity, practicality and efficiency. The effectiveness principle which is a measure of the success of curriculum implementation has also become the main focus for always developing curriculum. The effectiveness of a curriculum can be viewed from the aspect of quantity, namely the availability and readiness of curriculum components. While, the quality success can be seen from the results of the implementation of the curriculum.

Biology program since 2015 has implemented a curriculum in accordance with the National Higher Education Standards The implementation of the curriculum has begun with the development of supporting documents in its entirety. In the period of two years since the implementation in 2015, it was deemed necessary to conduct an evaluation. Periodic evaluation of curriculum implementation has been carried out by Quality Assurance Unit of Faculty of Mathematic and Natural Science through lecturer monitoring activities in two courses per study program per semester. The results of the monitoring and evaluation will provide an overview of the lecture process from preparation to implementation of the lecturer. However, how the overall learning achievement of students whose lecture process is based on national standards of higher education has not been described in detail.

This study aims to describe the effectiveness of curriculum implementation in the Biology study program, describe the implementation of curriculum implementation in the Biology study program, and describe the obstacles in implementing the curriculum.

\section{METHODS}

The research materials are all documents related to curriculum implementation in the Biology program. Another thing that is a source of data is the lecturer process in various courses that implement the curriculum according to the national standards of higher education and Faculty of Mathematic and Natural Science curriculum document [2]. Research materials are several kinds of instruments developed in this study.

Observations were made on the course of biology program. Data collection related to documents and observations is done by referring to relevant instruments to measure the 
effectiveness and implementation of the curriculum. Data collection instruments use observation sheets of curriculum documents and their implementation, lecturer and education staff questionnaires, and student interview sheets (Table I). Data were analyzed descriptively.

TABLE I. RESEARCH INSTRUMENT

\begin{tabular}{|l|l|}
\hline \multicolumn{1}{|c|}{ Research Objective } & \multicolumn{1}{c|}{ Instrument } \\
\hline $\begin{array}{l}\text { Effectiveness of } \\
\text { curriculum implementation } \\
\text { in Biology program }\end{array}$ & $\begin{array}{l}\text { Documentation sheet of } \\
\text { curriculum implementation } \\
\text { document }\end{array}$ \\
\cline { 2 - 2 } & $\begin{array}{l}\text { Documentation study sheet } \\
\text { related to the achievement } \\
\text { of the grades of students } \\
\text { who have completed the } \\
\text { course }\end{array}$ \\
\hline $\begin{array}{l}\text { Implementation of } \\
\text { curriculum in the Biology } \\
\text { program }\end{array}$ & $\begin{array}{l}\text { Documentation sheet } \\
\text { related to the } \\
\text { implementation of all } \\
\text { lectures }\end{array}$ \\
\cline { 2 - 2 } & $\begin{array}{l}\text { Questionnaires for } \\
\text { lecturers, education staff } \\
\text { and laboratory staff }\end{array}$ \\
\cline { 2 - 2 } & Questionnaire for students \\
\hline $\begin{array}{l}\text { Obstacles in curriculum } \\
\text { implementation }\end{array}$ & $\begin{array}{l}\text { Observation sheets, } \\
\text { interviews, and } \\
\text { questionnaires }\end{array}$ \\
\hline
\end{tabular}

\section{RESULT AND DISCUSSION}

\section{A. Effectiveness of curriculum implementation}

The effectiveness of Curriculum in the biology program is measured from several parameters, namely the availability of higher education national standard curriculum implementation documents, the value of student achievement and the implementation of lectures. In accordance with Unesa's curriculum development academic book [3], it is stated that each study program must have a written curriculum document, consisting of two books (documents). The document in question is Book-1 that contains: (1) Vision, Mission, and Objectives of Study Programs, (2) Profile of graduates, (3) Learning Outcomes that cover 4 types (attitudes, general skills, special skills, and knowledge); (4) Curriculum map; (5) Description of Subjects. Book-II which contains Semester Lesson Plan for all courses offered. Observations on the availability of curriculum documents are presented in Table II.

TABLE II. COMPLETENESS OF CURRICULUM DOCUMENTS

\begin{tabular}{|l|c|}
\hline Curriculum Document & Status \\
\hline Vision, Mission and Objectives & arranged \\
\hline Graduate Profile & arranged \\
\hline Study Program Achievement & arranged \\
\hline Curriculum Map & arranged \\
\hline Course Description & arranged \\
\hline
\end{tabular}

The availability of curriculum documents also includes lecture planning, which is operationally in the form of learning planning, which is the organization of the curriculum in the form of learning plans / plans, implementation of learning, conducting research, and follow-up to the results of the assessment. The data obtained about the implementation of each aspect in the design of the lectures has not reached $100 \%$ as presented in Table III.

TABLE III. AVAILABILITY OF DOCUMENTS RELATED to LECTURE DESIGN

\begin{tabular}{|l|c|}
\hline \multicolumn{1}{|c|}{ Lecture Design } & $\begin{array}{c}\text { Document } \\
\text { Realization (\%) }\end{array}$ \\
\hline $\begin{array}{l}\text { Lecturers have compiled the Semester } \\
\text { Lesson Plan }\end{array}$ & 100 \\
\hline $\begin{array}{l}\text { Semester Lesson Plan has been } \\
\text { reviewed by colleagues }\end{array}$ & 100 \\
\hline $\begin{array}{l}\text { Learning Support available } \\
\text { (book or student worksheet) }\end{array}$ & 90 \\
\hline Assessment sheet is available & 100 \\
\hline
\end{tabular}

Student learning outcomes that are needed to see the achievement of this curriculum are the mean percentage of the total value achieved for per semester. The summary of the percentage results is presented in Table IV. The distribution of values obtained shows a high enough percentage spread in the achievement of values A to B-. This phenomenon is found in value of students of biology program for $\mathrm{A}$ and $\mathrm{B}$.

TABle IV. Percentage of the Distribution of Achievement of the Value of Biology Program StudentS

\begin{tabular}{|c|c|c|c|c|c|c|c|c|c|c|c|}
\hline \multirow[b]{2}{*}{ Semester } & \multirow[b]{2}{*}{ Grade } & \multirow{2}{*}{$\begin{array}{l}\text { Number } \\
\text { of } \\
\text { courses }\end{array}$} & \multicolumn{9}{|c|}{ Average Value Percentage (\%) } \\
\hline & & & A & A- & $\mathrm{B}+$ & B & B- & $\begin{array}{l}\mathrm{C} \\
+\end{array}$ & $\mathrm{C}$ & $\mathrm{D}$ & $\mathrm{E}$ \\
\hline $\mathrm{I}$ & $\mathrm{A}$ & 8 & 11.5 & 19.3 & 20.8 & 20.0 & 13.3 & 8.5 & 5.1 & 1.4 & 0 \\
\hline II & A & 9 & 36.6 & 30.9 & 14.4 & 7.5 & 5.4 & 4.9 & 1.1 & 0.1 & 0 \\
\hline III & A & 7 & 31.2 & 40.2 & 18.1 & 6,7 & 3.1 & 0.9 & 0.2 & 0 & 0 \\
\hline IV & A & 7 & 32.2 & 20.1 & 37.2 & 6.5 & 3.1 & 0.7 & 0.2 & 0 & 0 \\
\hline I & $\mathrm{B}$ & 9 & 8.0 & 21.1 & 26.1 & 19.9 & 11.8 & 9.0 & 4.0 & 0 & 0 \\
\hline II & B & 10 & 8.5 & 23.4 & 26.2 & 19.9 & 10.2 & 7.9 & 3.9 & 0 & 0 \\
\hline
\end{tabular}


Table 4 gives information that most of the student scores are in the range of values from A to B, and are a good result of the implementation of higher education national standard curriculum. Results obtained through documentation studies on curriculum documentation shows good results, because the completeness of the main documents related to vision, mission, graduate profile, study program achievement, curriculum map and description of the course are complete with a number of courses arranged in the curriculum. Some curriculum implementation strategies were identified and attempt was made to advocate for an effective and efficient human resource development in basic need areas such as teaching, instructional materials design, program planners [4] and university move away from knowledge recycling to knowledge generation and remodel their curriculum [5].

The document is the direction implemented in other operational documents, namely in the form of Semester Lesson Plan, books, and also an assessment sheet. The preparation of the Semester Lesson Plan can be done relevant to achieving the vision and mission through the learning outcomes set for the study program. The availability of a good and complete document will facilitate the learning management process, so that it can get satisfactory results, namely the percentage of student value distribution is mostly in the $\mathrm{A}$ - $\mathrm{B}$ range.

The success of implementing the curriculum depends on lecturers, students, and campus policy. Lecturers' explicated design reasoning is mostly influenced by practical concerns, yet their own knowledge and beliefs play an important role at the start of the design process [2].

\section{B. Curriculum implementation}

Implementation data of curriculum can be obtained through documentation studies, as well as data collection through questionnaires. Implementation is measured by the successful implementation of the lecture design developed. The aspects observed in the lecture include facilitation of ecopreneurship insight, approach to learning and the stages of lectures carried out, such as on Table V.

TABLE V. LECTURE DESIGN IMPLEMENTATION

\begin{tabular}{|l|c|}
\hline \multicolumn{1}{|c|}{ Learning Implementation } & $\begin{array}{c}\text { Realization } \\
(\%)\end{array}$ \\
\hline $\begin{array}{l}\text { Lecturers facilitate the achievement of } \\
\text { ecopreneur insight by students ( eco } \\
\text { innovation, eco opportunity, eco } \\
\text { commitment ) }\end{array}$ & 100 \\
\hline $\begin{array}{l}\text { Collaborative, scientific, humanistic } \\
\text { learning approaches }\end{array}$ & 100 \\
\hline $\begin{array}{l}\text { The learning process consists of 3 stages } \\
\text { (introduction, core, and closing) }\end{array}$ & 100 \\
\hline Assessment sheet is available & 100 \\
\hline
\end{tabular}

The data in Table $\mathrm{V}$ provides information that all lectures are carried out relevant with higher education national standard curriculum. All lecture processes have been carried out in three stages by prioritizing the principles of collaborative, scientific and humanistic lectures. The lecture approach is very possible to facilitate ecopreneurship insight. Learning evaluation has also been carried out in a structured manner through the availability of assessment sheets. In other case, the perspective of Indonesian policy, Competency-Based Curriculum will be no longer implemented as the advent of National Qualification Framework (KKNI) would give great impact on the OutcomesBased Curriculum [6].

Assessment conducted is an important activity to develop all the potential of students through humanistic lectures. In detail the activities carried out assessment and follow-up are taken based on the results obtained outlined on Table VI and Table VII.

TABLE VI. IMPLEMENTATION OF LEARNING EVALUATION / ASSESSMENT

\begin{tabular}{|l|c|}
\hline \multicolumn{1}{|c|}{ Assessment Implementation } & $\begin{array}{c}\text { Realization } \\
(\%)\end{array}$ \\
\hline $\begin{array}{l}\text { Meet the principles of educative, authentic, } \\
\text { objective, accountable, and transparent }\end{array}$ & 90 \\
\hline $\begin{array}{l}\text { Strategies and assessment instruments are } \\
\text { in accordance with the indicators }\end{array}$ & 90 \\
\hline $\begin{array}{l}\text { Promote the principle of assessment for } \\
\text { learning and assessment as learning in } \\
\text { addition to assessment of learning }\end{array}$ & 60 \\
\hline Develop an assessment rubric & 70 \\
\hline $\begin{array}{l}\text { Conduct participatory assessments, } \\
\text { assignments, sub summative exams, and } \\
\text { summative exams }\end{array}$ & 100 \\
\hline $\begin{array}{l}\text { Processing value and interpretation of } \\
\text { assessment results }\end{array}$ & 100 \\
\hline
\end{tabular}

TABLE VII. FOLLOW-UP OF LEARNING EVALUATION / ASSESSMENT

\begin{tabular}{|l|c|}
\hline $\begin{array}{l}\text { Forms of follow-up on the results of } \\
\text { assessments conducted by lecturers }\end{array}$ & $\begin{array}{c}\text { Realization } \\
(\%)\end{array}$ \\
\hline Change learning strategies & 100 \\
\hline Give additional tasks & 100 \\
\hline $\begin{array}{l}\text { Performing a remediation test. } \\
\text { Starting from the odd semester of 2017- } \\
\text { 2018, all MKs conduct remediation } \\
\text { examinations if there are students who have } \\
\text { not reached the UTS score of at least 68 }\end{array}$ & 60 \\
\hline $\begin{array}{l}\text { Do remediation learning. } \\
\text { Starting from the odd semester of 2017- } \\
\text { 2018, all MKs conduct remediation } \\
\text { examinations if there are students who have } \\
\text { not reached the UTS score of at least 68 }\end{array}$ & 60 \\
\hline $\begin{array}{l}\text { Give individual guidance } \\
\text { Develop learning aids such as BAM, LKS, } \\
\text { Visualization Media or other forms }\end{array}$ & 100 \\
\hline
\end{tabular}




\section{Obstacles factors of curriculum implementation}

Obstacles factors of implementation curriculum in biology programs recorded through observation, interviews with lecturers, interviews with students, lecturer perceptions and various other relevant strategies. The factors that become obstacles are as follows.

1. Planning stage

During the implementation phase Semester Lesson Plan developed by the lecturers there are not in accordance. Some problems that cause is lecturer have different perceptions regarding the components Semester Lesson Plan after be disseminated.

2. Implementation Phase

Lecturers in general, teach do not see the Semester Lesson Plan, to ensure what learning activities are designed to be applied at certain meetings. One of them factor the cause is the lecturer has memorized the usual order of presentation.

3. Assessment Phase

The assessment phase carried out on a scheduled basis, sehi ngga relatively unhindered implementation, except middle test. Some courses organizes middle test more than once and about middle test yet corresponding with indicators in Semester Lesson Plan.

4. Follow up Phase

The follow-up has been carried out by the lecturer. This activity becomes due emphasis quality assurance unit of biology program has published a special assessment instrument to control the implementation aspects to be continued.

\section{CONCLUSION}

The conclusion in this study were 1) implementation of the biology curriculum have effective, 2) curriculum implementation in the biology program very good, and 3 ) obstacles factors of curriculum implementation in the biology program among others on planning stage, implementation stage and assessment stage.

\section{REFERENCES}

[1] R. Vanderlinde, J. van Braak, and R. Hermans, "Educational technology on a turning point: curriculum implementation in Flanders and challenges for schools," Educational Tech. Res. Dev., vol. 57, pp. 573584, August 2009.

[2] Tim Pengembang Kurikulum FMIPA Unesa, Panduan Implementasi Kurikulum Berciri Ecopreneurship, Surabaya: Universitas Negeri Surabaya, 2017.

[3] F. Boschman, S. McKenney and J. Voogt, "Understanding decision making in teachers' curriculum design approaches," Education Tech Res. Dev., vol. 62, pp. 393-416, 2014.

[4] D.B. Enu and F.E. Dibang, "Facilitating the UBE Curricula Implementation through Sustainable Human Resources Development," West African Journal of Research and Development in Education, vol. 8(1), pp. 61-65, 2001.

[5] O. Ajayi and B.D. Enu, "The challenges of the University as Agent of Social Change," Nigeria Journal of Curriculum Studies, vol. 16 (1), pp. 258-266, 2009.

[6] I. Solikhah, "National Qualification Framework (KKNI) in Curriculum Based on Learning Outcomes," Lingua, vol. 12(1), pp.1-22, 2015. 